\title{
Splenic Lymphangiomatosis with Inflammatory Signs and Elevated Serum Interleukin-6: A Case Report
}

\author{
Mikiko Ise ${ }^{1)}$, Toshinao Takenouchi' ${ }^{2)}$, Chikara Sakai ${ }^{1)}$
}

Lymphangiomatosis is a rare disorder believed to result from a developmental malformation of the lymphatic system. Lymphangiomatosis involves bone, soft tissues, and viscera in a diffuse fashion. We describe an unusual case of splenic lymphangiomatosis that was accompanied by remarkable inflammatory signs. A 38-year-old Japanese woman was admitted to our hospital because of gross splenomegaly. She presented with fatigue, anemia, elevated serum $\mathrm{C}$-reactive protein and polyclonal hypergammaglobulinemia. Her serum concentration of interleukin-6 (IL-6) was also elevated. She was born with lymphangiomatosis in the right leg, which was partially resected during infancy. Because of the risk of traumatic rupture, a total splenectomy was performed two weeks after admission. During postoperative follow-up examinations the patient's inflammatory signs and her serum IL-6 level returned quickly to normal. This could have been caused by a large release of IL-6 from the spleen. We confirmed by immunohistochemistry that IL-6 was produced within the spleen. Our findings indicate a strong association between splenic lymphangiomatosis and IL-6 production.

Key words Lymphangiomatosis; Spleen; Inflammation; Interleukin-6

\section{INTRODUCTION}

Lymphangiomatosis is a rare disorder characterized by abnormal proliferation of lymphatic channels. It is generally regarded as a congenital malformation of the lymphatic system. Histologically, the lesion is composed of cystic spaces of various sizes lined by endothelium and surrounded by connective tissue $^{1}$. Lymphangiomatosis occurs mainly in children and young adults less than 20 years of age ${ }^{2}$.

We encountered an unusual case of nonsystemic diffuse lymphangiomatosis of the spleen. The patient was born with lymphangiomatosis in the right leg. The splenic lymphangiomatosis was discovered incidentally at the age of 38 . The patient presented with remarkable inflammatory signs such as anemia and serum C-reactive protein (CRP) elevation. Serum interleukin-6 (IL-6) was also elevated. These abnormalities resolved dramatically soon after the patient underwent splenectomy. The unique

Received: Mar 5, 2004

Revised: Mar 18, 2004

Accepted: Jun 7, 2004

"Departments of Hematology-Oncology and ${ }^{2}$ Surgical Pathology, Chiba Cancer Center Hospital, Chiba, Japan

Address correspondence and reprint requests to Mikiko Ise, Department of Medicine, Matsudo Municipal Welfare Medical Center Hospital, Takatsuka-Shinden 123-13, Matsudo City, Chiba 270-2222, Japan clinical manifestations and postoperative course prompted us to report this case.

\section{CASE REPORT}

A 38-year-old Japanese woman was admitted to our hospital in September 1998 because of fatigue, anemia, and elevated serum CRP. A physical examination revealed gross splenomegaly $(5 \mathrm{~cm}$ under the costal margin). Elephantiasis of the right leg and soft microscopic lymphadenopathies in the right inguinal region were observed, but there was no skin infection or ulceration. The patient's medical history included lymphangiomatosis in her right leg at birth. The patient underwent partial resection of the lesion at 0,5 , and 19 years of age, but extensive involvement of soft tissues prevented complete excision. Her temperature at admission was $37^{\circ} \mathrm{C}$. There was no hepatomegaly. Laboratory investigation showed microcytic hypochromic anemia with 8.6 $\mathrm{g} / \mathrm{dl}$ hemoglobin. Her leukocyte count was $4.65 \times$ $10^{9} / \mathrm{l}$, platelet count $315 \times 10^{4} / \mathrm{l}$, and reticulocytes were $0.7 \%$. Urinalysis, clotting, and liver and kidney function were all normal. Iron was $17 \mu \mathrm{g} / \mathrm{dl}$ (normal range, $65-175 \mu \mathrm{g} / \mathrm{dl}$ ). CRP was $5.7 \mathrm{mg} / \mathrm{dl}$ (normal range, $\leqq 0.4 \mathrm{mg} / \mathrm{dl}$ ). Total serum protein was 8.8 $\mathrm{g} / \mathrm{dl}$ (albumin $35.1 \%$, gammaglobulin 43.2\%). Serum protein electrophoresis revealed polyclonal hyper- 
gammaglobulinemia: IgG $4130 \mathrm{mg} / \mathrm{dl}$ (normal range, 900-1600 mg/dl), IgA $274 \mathrm{mg} / \mathrm{dl}$ (normal range, $150-350 \mathrm{mg} / \mathrm{dl}$ ), IgM $332 \mathrm{mg} / \mathrm{dl}$ (normal range, $70-150 \mathrm{mg} / \mathrm{dl}$ ). The most remarkable finding was that the serum concentration of IL-6 was elevated to $30.6 \mathrm{pg} / \mathrm{ml}$ (normal range, 0.221-4.62 $\mathrm{pg} / \mathrm{ml}$ ). Abdominal ultrasonography and computed tomography examinations revealed an enlarged spleen with multiple low-density cystic lesions (Fig. 1). Gallium scintigraphy showed massive splenomegaly with parenchymatous defects. Examination of the bone marrow aspirate and a biopsy specimen showed a slight increase in the number of plasma cells $(3.0 \%)$ but no dysplastic features. Because of her history of lymphangiomatosis in the right leg, splenic lymphangiomatosis was suspected strongly, although a malignancy could not be excluded. Because of the risk of traumatic rupture, a total splenectomy was performed 16 days after admission. During surgery no other organs were found to be involved

\section{MATERIALS AND METHODS}

\section{Tissue Examination}

The surgical specimens were fixed in $10 \%$ buffered formalin and embedded in paraffin. Sections (4 $\mu \mathrm{m}$ thick) were cut and stained with hematoxylin and eosin for histological examination. Paraffinembedded sections were immunohistochemically stained by the standard streptavidin-biotinperoxidase method with an antibody against human IL-6 (H-183, rabbit polyclonal, Santa Cruz Biotechnology, Santa Cruz, CA).

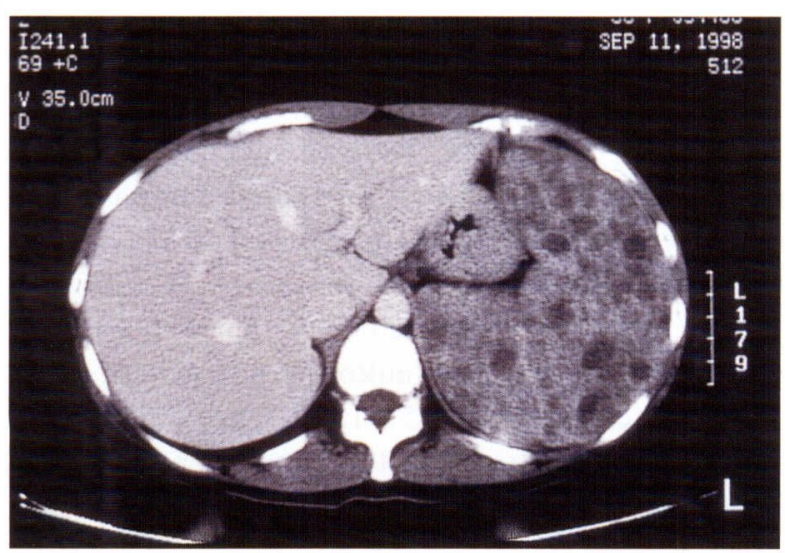

Fig. 1. Enhanced computed tomography scan of enlarged spleen showing multiple low-density cystic lesions involving most of the splenic parenchyma.

\section{Serum IL-6 Concentration}

The serum IL-6 concentration was measured by chemiluminescent enzyme immunoassay kit (Lumipulse, FUJIREBIO, Tokyo, Japan).

\section{RESULTS}

\section{Pathology}

The patient's resected spleen weighed $1350 \mathrm{~g}$ and measured $20 \times 12.5 \times 9.5 \mathrm{~cm}$. The surface was firm and nodular. The parenchyma was almost totally replaced by numerous cysts (Fig. 2). The cysts measured up to $2.0 \mathrm{~cm}$ in diameter, were surrounded by fibrous connective tissue, and contained clear yellowish serous fluid. Microscopically, the cysts were lined with a single layer of flattened endothelial cells and contained deeply eosinophilic amorphous material that resembled lymph (Fig. 3a). Some of the cysts had fused together, forming larger cavities. Interestingly, the stroma included a varied mixture of inflammatory cells including cytologically normal plasma cells, small lymphocytes, and neutrophils (Fig. 3b). The pathological diagnosis was lymphangiomatosis of the spleen.

\section{Cytokines}

The spleen cells producing the IL-6 protein were subjected to immunohistochemical analysis. Several cell populations reacted positively to antihuman IL-6 antibody (Fig. 4a). These included endothelial cells of the lymphangioma, lymphocytes, and plasma cells. The endothelial cells reacted the

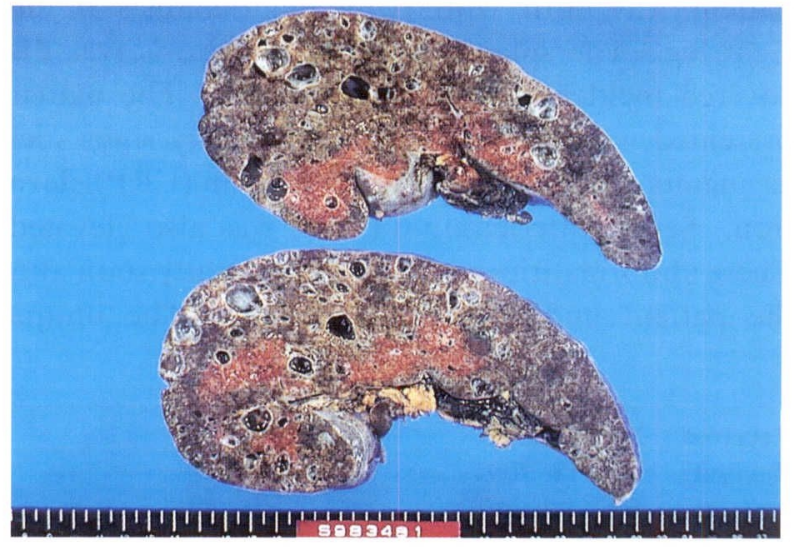

Fig. 2. Cut surface of the resected spleen showing extensive involvement and replacement of the normal parenchyma by numerous cysts. 

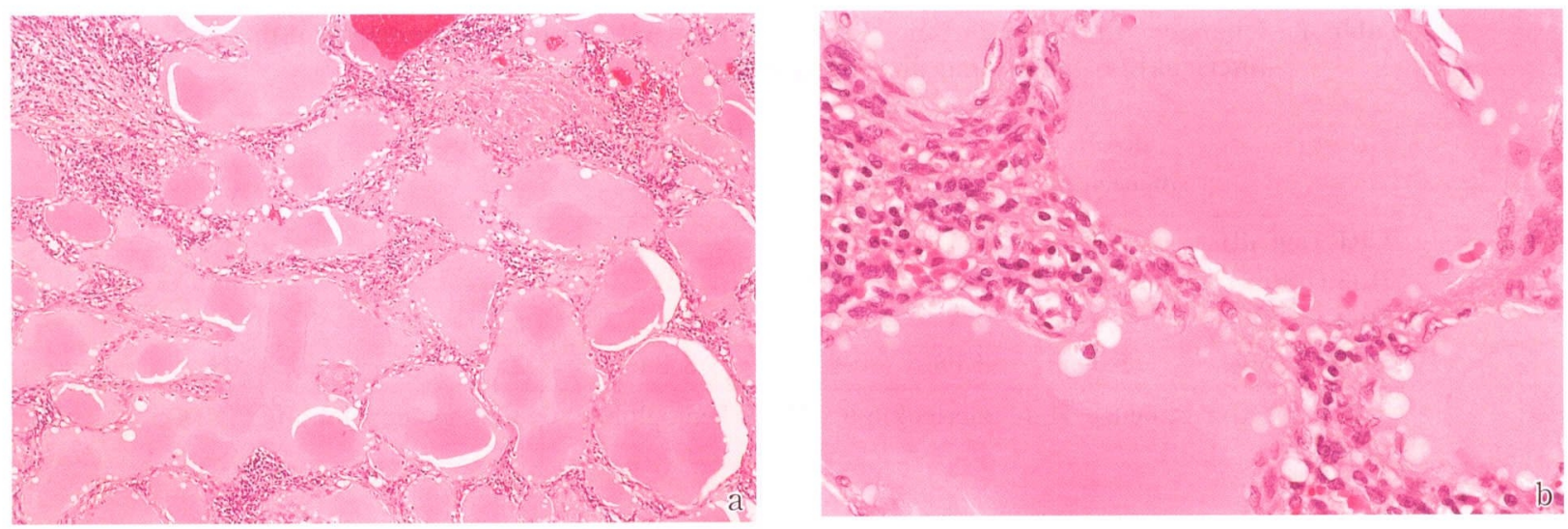

Fig. 3. Microscopic findings in the resected spleen. a. Representative section of the splenic lymphangiomatosis showing cystic spaces of various sizes lined with endothelial cells (hematoxylin-eosin staining, original magnification $\times 25)$. b. The stroma includes a varied mixture of inflammatory cells such as plasma cells, lymphocytes, and neutrophils (hematoxylin-eosin staining, original magnification $\times 400$ ).
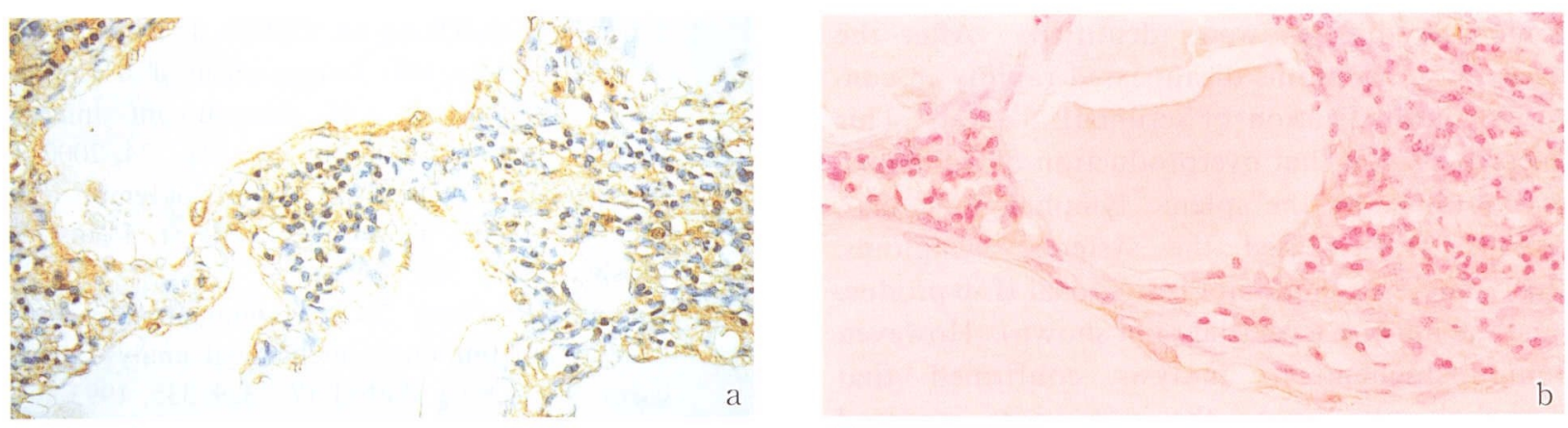

Fig. 4. Immunohistochemical findings in the resected spleen. a. Several cell populations exhibit positive reaction to anti-human interleukin-6 antibody (original magnification $\times 100$ ). b. Endothelial cells of the lymphangioma appear to be the most strongly positive of spleen cells (original magnification $\times 200$ ).

most strongly (Fig. 4b).

\section{Postoperative course}

The patient's postoperative course was uncomplicated. Systemic symptoms disappeared within a few days, and almost all laboratory values returned to normal soon after the splenectomy (Table 1). This disappearance of inflammatory signs coincided with normalization of the serum Il-6 concentration, suggesting that most of the IL-6 had been produced within and released from the enlarged spleen. The patient remains in good health. Now, over 5 years after the splenectomy, her hemoglobulin is $11.5 \mathrm{~g} / \mathrm{dl}$, CRP is $0.3 \mathrm{mg} / \mathrm{dl}$, and IL-6 is $2.94 \mathrm{pg} / \mathrm{ml}$. Hypergammaglobulinemia has persisted (total serum protein $8.2 \mathrm{~g} / \mathrm{dl}$; gammaglobulin $29.0 \%$ ). The leg lesion remains unchanged.

\section{DISCUSSION}

Lymphangioma is a rare disease generally regarded as a malformation of the lymphatic system. Congenital obstruction or agenesis of lymphatic tissue causes abnormal dilatation and mass-like proliferation of lymphatic channels ${ }^{3}$. Lymphangiomas occur most commonly in the neck (75\%) and axillary region $(20 \%)^{1}$. They sometimes, though rarely, involve the mediastinum, retroperitoneum, mesentery, omentum, and parenchymal organs such as the lung, gastrointestinal tract, spleen, liver, and bone. Lymphangioma that affect bone, soft tissue, or parenchymal organs in a diffuse or multifocal fashion are termed lymphangiomatosis ${ }^{1}$. Despite its benign origin, the prognosis of diffuse lymphangiomatosis depends on the organs involved and the extent of involvement ${ }^{4}$. Extensive liver, lung, or bone involvement can be fatal ${ }^{5-7}$.

The clinical manifestations in our case deserve 
Table 1 Changes in hemoglobin, serum C-reactive protein, gammaglobulin and interleukin- 6 before and after splenectomy.

\begin{tabular}{lccccccc}
\hline & \multirow{7}{*}{$\begin{array}{c}\text { Before } \\
\text { splenectomy }\end{array}$} & \multicolumn{7}{c}{ Time after splenectomy } \\
\cline { 3 - 8 } & & $1 \mathrm{mo}$ & $3 \mathrm{mo}$ & 6 mo & $1 \mathrm{y}$ & $3 \mathrm{y}$ & $5 \mathrm{y}$ \\
\hline CRP $(\mathrm{mg} / \mathrm{dl})$ & 5.7 & 1.4 & 0.8 & 1.2 & 0.7 & 0.5 & 0.3 \\
$\mathrm{IL}-6(\mathrm{pg} / \mathrm{ml})$ & 30.60 & ND & ND & ND & 3.38 & 3.45 & 2.94 \\
HGB $(\mathrm{g} / \mathrm{dl})$ & 8.6 & 9.3 & 10.3 & 11.8 & 11.6 & 11.2 & 11.5 \\
$\gamma$-Glb $(\mathrm{g} / \mathrm{dl})$ & 3.80 & 3.08 & 2.94 & 3.28 & 3.35 & 2.96 & 2.38 \\
\hline
\end{tabular}

CRP, C-reactive protein ; IL-6, interleukin-6 ; HGB, hemoglobin ; $\gamma$-Glb, gammaglobulin ; ND, not done.

attention. Although the lymphangiomatosis was confined to the patient's spleen and the right leg, she displayed systemic inflammatory signs such as microcytic hypochromic anemia, serum CRP elevation, and polyclonal hypergammaglobulinemia. Her serum IL-6 was elevated. No other infections or autoimmune diseases were identified. After the splenectomy, symptoms disappeared rapidly in concert with normalization of serum IL-6 level. This seemed to suggest that overproduction of inflammatory cytokines, by the splenic lymphangiomatosis, especially IL-6 caused the systemic symptoms. Unfortunately we could not verify local IL-6 production at the mRNA level (data not shown). However, immunohistochemical analysis confirmed that endothelial cells lining the cysts were involved mainly in the local IL-6. Our findings indicate a strong association between the splenic lymphangiomatosis and IL-6 production.

Lymphangioma traditionally has been treated by complete surgical excision. However, aggressive surgery is impossible in disseminated lymphangiomatosis ${ }^{7-8}$. In our case the patient's polyclonal hypergammaglobulinemia has continued. This may be due to the remnant lymphangiomatosis in the patient's right leg, which is probably producing IL-6 or other inflammatory cytokines in smaller quantities than the spleen. The persistence of this mass requires long-term follow-up that will assist us in better understanding the behavior of this benign lesion. Disseminated lymphangiomatosis can be a proliferative disorder; therefore, treatment with interferon, a cytokine with antiproliferative and antiangiogenic properties, may be effective against this disease ${ }^{2,9,10,11}$. We plan to administer interferon if our patient develops systemic inflammatory symptoms again.

\section{REFERENCES}

1 Fisher D, Hiller N: Case report: Giant tuberculous cystic lymphangioma of posterior mediastinum, retroperitoneum and groin. Clin Radiol 49: 215216, 1994

2 Laverdiere C, David M, Dubois J, Russo P, Hershon L, Lapierre JG : Improvement of disseminated lymphangiomatosis with recombinant interferon therapy. Pediatr Pulmonol 29: 321-324, 2000

3 Enzinger FM, Weiss SW : Tumors of lymph vessels. In: Soft Tissue Tumors. 3rd ed. St. Louis, MO, Mosby, pp679-700, 1995

4 Ramani P, Shah A: Lymphangiomatosis: Histologic and immunohistochemical analysis of four cases. Am J Surg Pathol 17: 329-335, 1993

5 Marymont JV, Knight PJ: Splenic lymphangiomatosis: A rare cause of splenomegaly. J Pediatr Surg 22: 461-462, 1987

6 Asch MJ, Cohen AH, Moore TC: Hepatic and splenic lymphangiomatosis with skeletal involvement: Report of a case and review of the literature. Surgery $76: 334-339,1974$

7 Avigad S, Jaffe R, Frand M, Izhak Y, Rotem Y: Lymphangiomatosis with splenic involvement. JAMA 236: 2315-2317, 1976

8 Morgenstern L, Bello JM, Fisher BL, Verham RP : The clinical spectrum of lymphangiomas and lymphangiomatosis of the spleen. Am Surg 58: 599-604, 1992

9 Tazelaar HD, Kerr D, Yousem SA, Saldana MJ, Langston C, Colby TV: Diffuse pulmonary lymphangiomatosis. Hum Pathol 24: 1313-1322, 1993

10 Reinhardt MA, Nelson SC, Sencer SF, Bostrom BC, Kurachek SC, Nesbit ME: Treatment of childhood lymphangiomas with interferon-alpha. J Pediatr Hematol Oncol 19: 232-236, 1997

11 Laverdiere C, David M, Dubois J, Russo P, Hershon L, Lapierre J-G : Improvement of disseminated lymphangiomatosis with recombinant interferon therapy. Pediatr Pulmonol 29: 321-324, 2000 